\title{
EFFECTS OF AUTUMN-APPLIED NITROGEN AND METHOD AND FREQUENCY OF DEFOLIATION ON A RYEGRASS/WHITE CLOVER SWARD
}

\author{
R. S. ScotT \\ Invermay Agricultural Research Centre, Mosgiel*
}

\section{A bstract}

Ammonium nitrate was applied during March or April to an (Ariki) ryegrass/(Huia) white clover sward. The subsequent effects on winter and spring production, clover content and herbage nitrogen content were examined following three frequencies of winter defoliation by cutting and grazing.

Herbage yields of 10.2 and $7.7 \mathrm{~kg} \mathrm{DM} / \mathrm{ha} / \mathrm{kg} \mathrm{N}$ applied were obtained in winter following March and April applications of nitrogen, respectively. Early spring yields were slightly depressed by autumn-applied nitrogen while late spring yields were unaffected. For the period March-November, responses to nitrogen fertilizer were $4.8 \mathrm{~kg} \mathrm{DM} / \mathrm{ha} / \mathrm{kg} \mathrm{N}$ applied.

Only in the presence of nitrogen applied in March did grazing provide higher yields than cutting. Grazing depressed early spring yields but increased late spring yields. Over the period MarchNovember, yields did not differ according to method of defoliation.

Three winter defoliations provided higher winter. yields, midspring and total yields (March-November) than less frequent defoliations. Early and late spring yields were unaffected by the frequency of defoliation.

\section{INTRODUCTION}

IN Otago and. Southland there has been a marked change in wintering systems away from dependence on winter forage crops towards a\&grass wintering. This latter system is based on the early closing of pastures in autumn followed by early winter grazing. Under this system it is considered that increased winter growth of pasture will result from the recycling of herbage nitrogen by the grazing animal. It is also considered that this production can be further increased by the application of fertilizer nitrogen.

Scott (1963) ; using a cutting technique, and Brougham (1970) using the grazing animal, both found that three winter defolia-

\footnotetext{
*Present address: Agronomy Department, Massey University, Palmerston-
} North. 


\section{RYEGRASS/WHITE CLOVER}

tions provided higher winter yields of herbage than less frequent defoliation. This would suggest that, irrespective of any effects of nutrient status and animal treading on winter production, the over-riding effect was due to the defoliation per se.

Harris and Brown (1970) recorded a depression in yield from frequent compared with infrequent grazing (described by the authors as "moderate" and "hard" grazing). They demonstrated that this depression was due to animal treading. The disparity between these results and those previously cited lies in the frequency and intensity of the grazing treatments. On the "moderate" grazing treatment of Harris and Brown, which most closely approximated the grazing treatments imposed by Scott and Brougham, the former found no deleterious effects from animal treading.

It was the objective of this experiment to further measure the net effects of different frequencies of winter grazing on production and to attempt to apportion the effects among those of defoliation, recycled nitrogen and the treading effects of the grazing animal. Because of the implications in practical farming already discussed, the effects of applying nitrogen fertilizer in early and late 'autumn were also examined.

\section{EXPERIMENTAL}

The experiment was conducted on a highly fertile Wingatui silt loam at Invermay Agricultural Research Centre. The sward was two years old when the experiment was commenced, having been sown to a mixture of 'Grasslands Ariki' ryegrass (Lolium (perenne $\mathbf{x}$ multiflorum) $\mathbf{x}$ perenne) and 'Grasslands Huia' white clover (Trifolium repens).

The experiment was designed as a three replicate $2^{3}$ factorial split into three subplots. Treatments were as follows:

\section{FACTORIAL TREATMENTS}

\begin{tabular}{lccc}
\hline Nitrogen & Time of Application & Defoliation Method \\
\hline No nitrogen & mid-March & Cutting \\
$60 \mathrm{~kg} / \mathrm{ha}$ nitrogen & mid-April & & Grazing \\
& SPLIT-PLot Treatments & \\
Defoliated: & May, June, July & \\
& & June, July & \\
& & July & \\
\hline
\end{tabular}


TABLE 1: CUMULATIVE WINTER YIELDS AND SPRING YIELDS OF AVAILABLE DRY MATTER $(\mathrm{kg} / \mathrm{ha})$

\begin{tabular}{|c|c|c|c|c|c|c|c|}
\hline $\begin{array}{l}\text { Season : } \\
\text { Harvest: }\end{array}$ & i - & $\begin{array}{l}W \quad i \quad n \\
\\
\\
1+2\end{array}$ & $r-1$ & 4 & ${ }_{5}$ Spring & -1 & Total \\
\hline $\begin{array}{l}\text { Level of Nitrogen: } \\
\text { No nitrogen } \\
\text { Nitrogen } 60 \mathrm{~kg} / \mathrm{ha}\end{array}$ & $\begin{array}{l}1390 \mathrm{bB} \\
1940 \mathrm{aA}\end{array}$ & $\begin{array}{l}1470 \mathrm{bB} \\
2070 \mathrm{aA}\end{array}$ & $\begin{array}{c}1490 \mathrm{bB} \\
2010 \mathrm{aA}\end{array}$ & $\begin{array}{l}70 \mathrm{bA} \\
80 \mathrm{aA}\end{array}$ & $\begin{array}{l}1350 \mathrm{aA} \\
1180 \mathrm{bB}\end{array}$ & $\begin{array}{l}1570 \mathrm{aA} \\
1500 \mathrm{aA}\end{array}$ & $\begin{array}{l}4480 \mathrm{bA} \\
4770 \mathrm{aA}\end{array}$ \\
\hline $\begin{array}{l}\text { Method of defoliation: } \\
\text { cut } \\
\text { Grazed }\end{array}$ & $\begin{array}{l}1660 \mathrm{aA} \\
1670 \mathrm{aA}\end{array}$ & $\begin{array}{l}1740 \mathrm{aA} \\
1800 \mathrm{aA}\end{array}$ & $\begin{array}{l}1730 \mathrm{aA} \\
1770 \mathrm{aA}\end{array}$ & $\begin{array}{c}120 \mathrm{aA} \\
40 \mathrm{aA}\end{array}$ & $\begin{array}{l}1450 \mathrm{aA} \\
1080 \mathrm{bB}\end{array}$ & $\begin{array}{l}1360 \mathrm{bA} \\
1700 \mathrm{aA}\end{array}$ & $\begin{array}{l}4660 \mathrm{aA} \\
4590 \mathrm{aA}\end{array}$ \\
\hline $\begin{array}{l}\text { Time of application: } \\
\text { March. } \\
\text { April } \\
\text { c v } \%\end{array}$ & $\begin{array}{l}1830 \mathrm{aA} \\
1500 \mathrm{bB} \\
8.7\end{array}$ & $\begin{array}{c}1900 \mathrm{aA} \\
1640 \mathrm{bB} \\
13.3\end{array}$ & $\begin{array}{l}1840 \mathrm{aA} \\
1660 \mathrm{bB} \\
16.4\end{array}$ & $\begin{array}{c}90 \mathrm{aA} \\
70 \mathrm{aA} \\
29.8\end{array}$ & $\begin{array}{c}1230 \mathrm{bA} \\
1300 \mathrm{aA} \\
8.9\end{array}$ & $\begin{array}{l}1480 \mathrm{aA} \\
1580 \mathrm{aA} \\
32.9\end{array}$ & $\begin{array}{l}4640 \mathrm{aA} \\
4610 \mathrm{aA} \\
\quad 9.8\end{array}$ \\
\hline $\begin{array}{c}\text { Frequency of defoliation: } \\
\text { May, June, July } \\
\text { June, July } \\
\text { cv } \%\end{array}$ & 1670 & $\begin{array}{c}1950 \mathrm{aA} \\
1590 \mathrm{bB} \\
11.6\end{array}$ & $\begin{array}{c}1990 \mathrm{aA} \\
1640 \mathrm{bB} \\
1620 \mathrm{bB} \\
15.0\end{array}$ & $\begin{array}{r}70 \mathrm{aA} \\
60 \mathrm{aA} \\
140 \mathrm{aA} \\
25.9\end{array}$ & $\begin{array}{l}1360 \mathrm{aA} \\
1280 \mathrm{aA} \\
1140 \mathrm{bB} \\
13.3\end{array}$ & $\begin{array}{l}1560 \mathrm{aA} \\
1560 \mathrm{aA} \\
1470 \mathrm{aA} \\
12.7\end{array}$ & $\begin{array}{c}4980 \mathrm{aA} \\
4540 \mathrm{bB} \\
4370 \mathrm{cc} \\
11.9\end{array}$ \\
\hline
\end{tabular}


Nitrogen was applied as ammonium nitrate $(34 \% \quad \mathrm{~N})$. All treatments were closed from defoliation on March 15, 1971 when the March nitrogen treatment was applied. The April 'nitrogen treatment received its application one month later.

The split-plots allocated to defoliation by grazing measured $6.60 \mathrm{~m} \times 5.67 \mathrm{~m}$ and those defoliated by cutting measured $6.60 \mathrm{~m} \times 2.28 \mathrm{~m}$. Strips $0.61 \times 6.0 \mathrm{~m}$ were cut for yield estimation prior to each defoliation treatment.

To avoid confusion with cutting and defoliation treatments, results of yield measurements will be hereafter referred to as harvests. These harvests were made on the following dates:
Harvest 1 17/5/71
Harvest 2 17/6/71
Harvest 3 19/7/71
Harvest $46 / 9 / 71$
Harvest 5 14/10/71
Harvest $6 \quad 19 / 11 / 71$

Clippings were discarded on the cutting treatments and returned and partly consumed by sheep on the grazing treatments.

The so-called winter period in this experiment extended from May to July and the spring period from August to November.

Two mature Romney ewes previously "conditioned" in holding paddocks were confined to each plot of the grazing treatment. This provided a high stocking intensity of 534 ewes/ha. Ewes remained on the treatments (from about one to three days) until such time as the pasture was defoliated to mowing height (4$5 \mathrm{~cm}$ ) of the cutting treatment. Error was present in the estimation of equality of grazing height and is accepted as part of the experimental error.

\section{RESULTS}

\section{Winter Yields of Herbage}

The effects of treatments on cumulative winter yields and on yields of individual harvests in spring are presented in Table 1.

Yields from the combined harvests $1+2+3$ were in some instances lower than those from harvests $1+2$. This discrepancy arose from within-plot variability coupled with very low yields from the treatments which had been defoliated prior to the third harvest. In the treatment defoliated twice prior to the third harvest, for example, yields ranged from 10 to $150 \mathrm{~kg} /$ ha dry matter. Sampling at each harvest was made at randomiy selected sites within plots on the assumption that they were productively homogeneous.' Obviously this was not the case and accounts for the differences shown in the data. 
At each harvest there were highly significant responses to nitrogen application. Over the total winter period, nitrogen as a main effect gave yield increases of $520 \mathrm{~kg} / \mathrm{ha}$ dry matter, representing a response of $8.7 \mathrm{~kg} \mathrm{DM} / \mathrm{ha} / \mathrm{kg} \mathrm{N}$.

There was no difference in yield between the two methods of defoliation as a main treatment effect but they did interact with time of nitrogen application, as will be described later.

March application of nitrogen gave greater yields $(P<0.01)$ at each cut than April application of nitrogen. The difference declined linearly from $330 \mathrm{~kg} / \mathrm{ha}$ at the first harvest to $180 \mathrm{~kg} / \mathrm{ha}$ at the third harvest.

At harvests 1 and $1+2$ there were highly significant interactions of time of application and nitrogen treatments as shown in Table 2 (a) .

TABLE 2: INTERACTION OF TIME AND LEVEL OF NITROGEN APPLICATION ON YIELD

(kg DM/ha)

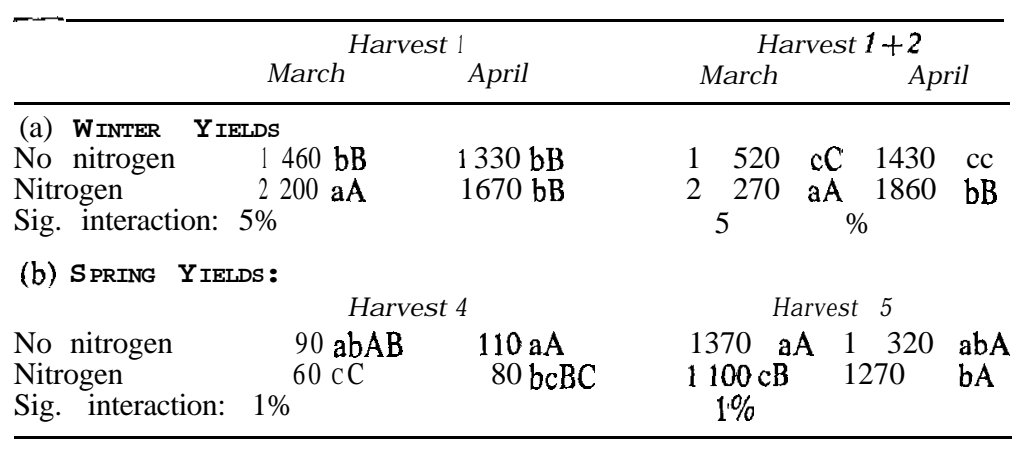

At- the first harvest in May, nitrogen increased pasture yields following March application only. The combined harvests $1+2$ showed that the nitrogen response was greater from March application than from April application. This superiority was maintained throughout the winter period as shown in Table 4 (a).

A significant interaction between the method of defoliation and time of nitrogen application is shown in Table 3.

Grazing achieved greater yields than cutting following the March application of nitrogen, but not following the April application.

The combined yields of harvests $1+2+3$ representing total winter production, provided significant main treatment effects 
RYEGRASS/WHITE CLOVER

TABLE 3: INTERACTION OF METHOD OF DEFOLIATION AND TIME OF NITROGEN APPLICATION ON COMBINED YIELDS OF HARVESTS $1+2(\mathrm{~kg} / \mathrm{ha} \mathrm{DM})$

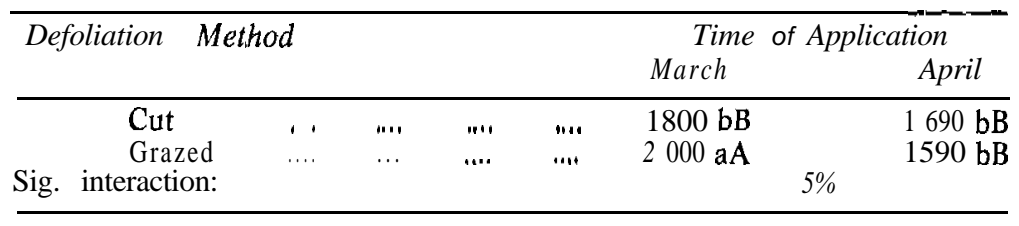

as already shown in Table 1 . These effects are best examined in the three factor interaction presented in Table 4 (a).

TABLE 4: INTERACTION OF METHOD OF DEFOLIATION AND TIME AND LEVEL OF NITROGEN APPLICATION ON YIELDS (kg DM/ha)

\begin{tabular}{lllll}
\hline \multicolumn{4}{c}{ No Nitrogen } & \multicolumn{2}{c}{ Nitrogen } \\
& $\begin{array}{c}\text { March } \\
\text { Appln. }\end{array}$ & $\begin{array}{c}\text { April } \\
\text { Appln. }\end{array}$ & March & Appln. \\
Appln.
\end{tabular}

The above results do not show any difference in yields between cutting and grazing in the absence of applied nitrogen. No comparison can be made between March and April treatments without nitrogen since they were both closed at the same time. In the presence of nitrogen applied in March, yields were significantly greater from grazing than from cutting. When nitrogen was applied in April, yields did not differ between grazing and cutting.

\section{S PRING Y IEIDS OF HERBAGE}

At the first harvest taken in spring (see Table 1, harvest 4), nitrogen provided a small but significant increase in yields, while at the second spring harvest (harvest 5) nitrogen significantly depressed yields. At the final spring harvest (harvest 6) there were no measurable effects from nitrogen. For the entire 
experimental period (March to November) nitrogen provided a net increase in yields of $290 \mathrm{~kg} / \mathrm{ha}$.

Cutting gave higher early spring yields (harvests 4 and 5) than grazing, while at the final harvest this pattern of yield response was reversed. For the entire experimental period, yields did not differ according to method of defoliation.

In the spring harvests and for the entire experimental period, there were no marked main effects of time of nitrogen application on yield although there were significant interactions with the level of nitrogen treatments. At harvest 5 (see Table 2 (b)) there was a greater reduction in yield following March application of nitrogen than following April application.

There was a greater depression in yields at harvest 5 (see Table 4 (b)) following grazing in the presence of nitrogen this effect being similar for both March and April applications of nitrogen.

No interactions were recorded for yield at the final cut nor for yield summed over the entire experimental period.

\section{PASTURE COMPOSITION}

At each of the three winter harvests, the sward consisted of approximately $95 \%$ grass and $5 \%$ clover; the only marked difference in composition (harvest 6) was that due to method of defoliation. This is shown in Table 5 in the percentage clover present.

TABLE 5: EFFECT OF LEVEL OF NITROGEN APPLICATION AND METHOD OF DEFOLIATION ON PERCENTAGE CLOVER

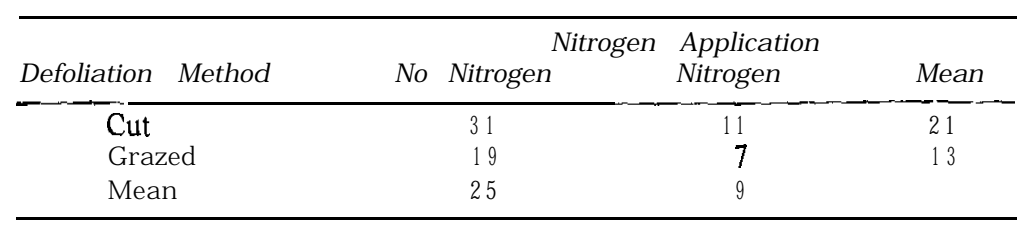

Defoliation by cutting appeared to increase clover content of the sward compared with grazing and this effect was greater in the absence of applied nitrogen.

\section{Herbage Nitrogen Levels}

Analysis of mixed herbage samples taken from harvests 3 and 4 showed that grazing significantly increased het-bage nitrogen 
RYEGRASS/WHITE CLOVER

TABLE 6: EFFECT OF METHOD OF DEFOLIATION ON NITROGEN CONCENTRATION IN MIXED HERBAGE ( $\% \mathrm{~N}$ in DM)

\begin{tabular}{|c|c|c|c|}
\hline \multirow{2}{*}{\multicolumn{2}{|c|}{ Treatment }} & \multicolumn{2}{|c|}{ Harvest } \\
\hline & & 3 & 4 \\
\hline & $\begin{array}{l}\text { cut } \\
\text { Grazed } \\
\text { cv \% }\end{array}$ & $\begin{array}{l}4.13 \mathrm{bB} \\
4.96 \mathrm{aA} \\
9.5\end{array}$ & $\begin{array}{l}3.27 \mathrm{bB} \\
3.96 \mathrm{aA} \\
7.6\end{array}$ \\
\hline
\end{tabular}

levels compared with cutting. These results are presented in Table 6.

The application of nitrogen did not significantly increase herbage nitrogen levels although the effect approached significance $(\mathrm{P}<0.05)$ at harvest 3 .

\section{DISCUSSION}

\section{WINTER Y IELDS OF HERBAGE}

Herbage yield responses to applied nitrogen of 7.7 to $10.2 \mathrm{~kg}$ $\mathrm{DM} / \mathrm{ha} / \mathrm{kg} \mathrm{N}$ applied were similar to those recorded previously by Scott (1963) in the same environment, and fall within the broad range of 3 to $20 \mathrm{~kg} \mathrm{DM} / \mathrm{ha} / \mathrm{kg} \mathrm{N}$ applied as reported , by O'Connor and Gregg (1971). By applying nitrogen in March rather than April an additional $2.4 \mathrm{~kg} \mathrm{DM} / \mathrm{ha} / \mathrm{kg} \mathrm{N}$ applied (see Table 2 (a)) was obtained in late autumn and early winter, when conditions for growth were more favourable.

Results of this experiment confirm the findings of Scott (1963) and Brougham (1970). They also confirm the practice of early winter grazing of autumn-saved grass followed by further defoliations. One of the penalties of this practice, should it be possible to apply it to the farm as a whole, would be to decrease the availability of feed in late winter. In practice, however, this problem does not arise as paddocks of saved grass are sequentially harvested throughout winter. This provides a compromise between the production of a maximum amount of herbage and the provision of late winter feed.

From the evidence available in this experiment it is not possible to identify any single factor as the cause of the net effects of frequent defoliation in increasing yields. In all likelihood several factors were operating independently. The most important would be, (1) nitrogen recycled by grazing animals, which would stimulate production, as shown by the work of Sears (1953) and Frame and Hunt (1971) for example; (2) the effects of winter 
treading in depressing yields as noted by Harris and Brown (1970) ; and (3) losses in available herbage on swards infrequently defoliated through senescence and decay.

There is some evidence to suggest that nitrogen recycled by grazing animals was exerting some effect on yields. This is shown in Table 4 (a) where treatments receiving nitrogen in March gave higher yields when grazed than when cut. In this case any deleterious effects of treading must have been more than compensated for by the benefits of recycled herbage nitrogen. The absence of any such effect on the treatment receiving nitrogen in April can be explained by the lower soil temperatures following nitrogen application and the poorer potential for growth and response. The absence of any difference in yield between grazing and cutting on the March and April no-nitrogen treatments (which in effect are the same treatment) is probably due to the benefit of recycled nitrogen being negated by the effects of treading. On these treatments there was less herbage and hence less nitrogen available for recycling compared with the treatments that received applied nitrogen.

\section{SPRING Y IEIDS OF HERBAGE}

After a period of herbage yield response to applied nitrogen the subsequent small depression in yields at harvest 5 follows an established pattern (Walker, 1956). Herbage nitrogen levels at harvest 4 suggest that this was associated with lower levels of available soil nitrogen. In all probability there would have been a number of other contributing factors, such as a loss in tiller density on the heavier winter producing nitrogen treatments and the poorer light interception following defoliation of this treatment (Brougham, 1956).

This depression was of only a temporary nature as can be seen in the similarity of yields between the nonitrogen and nitrogen treatments at the final cut, irrespective of the differing amount of clover present. It is probable that the recycling of autumn-applied nitrogen on grazing treatments was carried through to November while on cut treatments the greater amount of clover was contributing to the pool of available soil nitrogen.

Early nitrogen application (March compared with April), while providing an additional $180 \mathrm{~kg} / \mathrm{ha}$ DM during winter months, resulted in a loss in yields of the same order in spring. Thus March application of nitrogen had the effect of shifting the availability of feed from spring to winter. 


\section{Cutting versus Grazing}

The effects of cutting versus grazing on early spring yields were a reversal of those obtained in winter. Yields under cutting were higher even though lower herbage nitrogen levels were recorded. This suggests that winter treading "was, as found by Harris and Brown (1970), limiting spring production of herbage. By the final cut in November these, effects had disappeared.

The high percentage clover content on cut swards was presumably in response to lower soil nitrogen levels following the removal of herbage nitrogen in the clippings.

Treatments defoliated most frequently in winter provided higher yields in early spring, demonstrating the advantages of maintaining herbage at a short and leafy stage of growth. However, the similarity of yields between defoliation treatments at the final cut indicate that these treatments are unlikely to have exerted a lasting effect on sward productivity.

\section{CONCLUSIONS}

The benefit obtained from autumn-applied nitrogen as a means of increasing the winter production of saved grass was in close agreement with previous work carried out by the author and with that of other workers. For purposes of feed budgeting, a response of about $10 \mathrm{~kg} \mathrm{DM} / \mathrm{ha} / \mathrm{kg} \mathrm{N}$ applied to a ryegrass/white clover sward is considered to be a reliable estimate.

Sufficient evidence has been obtained from this experiment and those of other workers to recommend the rotational grazing of saved grass with the aim of completing about three rotations during winter. Defoliation to a height of $4 \mathrm{~cm}$ is recommended. Care needs to be taken to ensure that this management is not applied to the whole farm as it could result in high overall winter yields at the expense of late winter feed availability. The results suggest that the rotational grazing of saved grass will not cause any loss in spring production of pasture, and may increase midspring yields.

\section{ACKNOWLEDGEMENTS}

The author wishes to acknowledge the assistance of W. Brown and L. Cranshaw in the field and to thank J. L. Grigg for the nitrogen analyses of herbage. 


\section{REFERENCES}

Brougham, R. W., 1956: Australian Journal of Agricultural Research, 7: 377-87

1970: Proceedings of the N.Z Grassland Association, 32: 137-44.

Edmond, D. B, 1958: N.Z. Journal of Agricultural Research, 1: 319-28. Frame, J.; Hunt, I. V., 1971: Journal of the British Grassland Society, 26: 163 .

Harris, A. J.; Brown, K. R., 1970: Proceedings of the N.Z. Grassland Association, 32: 191-J.

O'Connor, M. B.; Gregg, P. E. H., 1971: Proceedings of the N.Z. Grassland Association, 33: 26-34.

Scott, R. S., 1963: N.Z. Journal of Agriculture, 106: 117-21.

Sears, P. D., 1953: N.Z. Journal of Science and Technology, 35A (Suppl. 1): 1-29.

Walker, T. W. 1956: Proceedings of the 7th. International Grassland Congress: $157-67$. 